\title{
Tobacco as Cultural Signifier: A Cultural History of Masculinity and Nationality in Habsburg Hungary ${ }^{1}$
}

\section{Alexander Maxwell, Victoria University of Wellington, New Zealand}

Abstract: Since tobacco smoking acquired important patriotic symbolism in nineteenth century, the history of tobacco sheds light on Hungarian nationalism. Hungarian tobacco growers found the Austrian tobacco tariff policy harmful to their interests, particularly when war disrupted the supply of American tobacco in potential export markets. Pushing for a different tariff, Hungarian patriots turned smoking into a marker of Hungarian patriotism. Tobacco symbolism was prominent during Hungary's 1848 Revolution, not least because tobacco acquired revolutionary symbolism in Italy and Germany as well. The culture of patriotic tobacco corresponded to revolutionary national ideas in that it mostly transcended class barriers but excluded women.

Keywords: Reform Era, Tobacco, Nationalism, Social History, Austria-Hungary

Biography: Alexander Maxwell teaches history at Victoria University of Wellington, New Zealand, where he also directs the Antipodean East European Study Group. He studied physics and history for his Bachelor's degree (University of California, Davis), completed MA degrees in History (University of Wisconsin, Madison) and Nationalism Studies (Central European University, Budapest) before completing his Ph.D. in history (University of Wisconsin, Madison). He is the author of Choosing Slovakia: Slavic Hungary, the Czechoslovak Language, and Accidental Nationalism, has translated Jan Kollár's Panslav tract Reciprocity Between the Tribes and Dialects of the Slavic Nation, and edited the volumes The East-West Discourse, Symbolic Geography and its Consequences and The Comparative Approach to National Movements: Miroslav Hroch and Nationalism Studies. He is presently working on Patriots Against Fashion, a history of nationalism and clothing.

\footnotetext{
${ }^{1}$ See Maxwell d for a previous version of this article.
} 
Maxwell, Alexander. "Tobacco as Cultural Signifier: A Cultural History of Masculinity and Nationality in Habsburg Hungary." AHEA: E-journal of the American Hungarian Educators Association, Volume 5 (2012): http://ahea.net/e-journal/volume-5-2012

During his 1850-1851 voyage to Hungary, American traveller Charles Loring Brace characterized tobacco smoking as a quintessentially Hungarian habit. While staying on a rural Hungarian estate, he wrote that "it was rather characteristic of Hungarian manners, that the last thing I saw before going to sleep of my companion [...] was a long pipe protruding from the bed-clothes, and the first thing which met my eye in the morning, was a cloud of smoke gently ascending from the same pile of blankets and pillows" (99). Elsewhere in the same volume, Brace provides a sociological profile of Hungarian smokers:

The clergyman walks the streets with his pipe in his mouth; the Bauer [farmer] smokes at every meal and all through the long evenings; the gentleman plies the cigar, wherever he is, from morning to night, in fair weather and foul, in work or in play. It has become a national habit. (367)

One might be sceptical of Brace's account: foreign travellers sometimes exaggerate or misunderstand the significance of what they see. Hungarian politicians in the Austrian Reichsrat, however, made remarkably similar claims to national exceptionalism, professing on 19 September 1860 that for Hungarians smoking had "become second nature, like one's daily bread" [zur zweiten Natur geworden, wie das alläglich Brot] (Silvestri 644). Indeed, one deputy declared that "We all know that nowhere else in the world is so much tobacco smoked as in Hungary, and that smoking has become an integral requirement in the life of the people" [Wir wissen Alle, daß nirgends so viel Tabak geraucht wird, wie in Ungarn, daß dort das Rauchen mit den Bedürfnissen des Volkslebens sich verwachsen hat] (Silvestri 639). The processes which made the smoking of American leaves a national symbol in the Danube basin deserve historical study. The story of Hungarian national smoking during the nineteenth century links economic interests to cultural imagination. Smoking, as a national symbol, also links popular understandings of the nation to distinctions of class, ethnicity and most importantly gender: Hungarians saw smoking not only as national, but as noble and masculine.

Economic tensions between the Hungarian nobility and the Habsburg monarchy explain why tobacco first acquired symbolic importance in the Hungarian collective psyche. At the end of the eighteenth century, when smoking first became a patriotic symbol, the Hungarian crown belonged to the Habsburg dynasty. Much as Hungarians found themselves under imperial rule, so too did the Hungarian tobacco industry find itself under Austrian regulation.

The history of Austrian tobacco legislation in this period is primarily the history of a state monopoly. When tobacco had first appeared in the Habsburg Empire in the sixteenth century, the dynasty had attempted to ban the substance (Sandgruber a 211-12). Prohibition, however, merely led to smuggling, and deprived the state of potential tax revenues. In 1784 Empress Maria Theresa (ruled 1740-1780) created a state monopoly for the core lower Austria, Bohemia, Graz, Klagenfurt, Moravia, Carniola and Galicia. It proved profitable, and Maria Theresa's successor Joseph II (ruled 1780-1790) expanded the monopoly to Bukovina and Salzburg in 1800 and 1809, respectively. In 1830, Francis II (ruled 1792-1835) further extended it to Tyrolia and Dalmatia (Hitz and Huber 191). Confusingly, nineteenth-century documents refer to this monopoly with several names, including the Apaldo, the Abaldo, and the Tabakregie. The institution underwent further 
Maxwell, Alexander. "Tobacco as Cultural Signifier: A Cultural History of Masculinity and Nationality in Habsburg Hungary." AHEA: E-journal of the American Hungarian Educators Association, Volume 5 (2012): http://ahea.net/e-journal/volume-5-2012

name changes both during and after the Nazi period. Nevertheless, an Austrian state monopoly of tobacco endured in some form under some name until Austria joined the European Union: in 1992, anti-trust legislation forced Vienna to disband the monopoly (Hitz and Huber; Matis and Bachinger 210-32). Continuity through so many upheavals testifies to popular acceptance of a state tobacco monopoly in the core Austrian lands, and perhaps to the monopoly's suitability to Austrian conditions.

Hungary, however, was a different story, since a tobacco monopoly conflicted with the interests of farmers, both large landowners and smaller farmers. Tobacco does not grow in high altitudes, and in German Austria the tobacco industry was a question of import and distribution. In Hungary, by contrast, tobacco grows well, and makes an important cash crop. Policies devised for Austria, therefore, had little chance of serving Hungarian interests.

Tension between Hungarian producers and Austrian bureaucrats became an important political issue during the American revolution. The conflict disrupted imports of Virginian tobacco, and scarcity led to higher European prices (Benkó 29; von Szapary 23). Hungarian farmers found that tobacco had become a very valuable commodity. By expanding Hungarian production to serve the export market, several fortunes were made. Low export taxes of 1.5 kreuzer per centner (c. 50 kilograms) facilitated this lucrative trade. As late as 1830, Hungarian landowners reminisced that "during the American war of independence, Hungarian tobacco was exported in great quantities to Germany and the Netherlands, and all factories in these countries use our leaves" (Orosz 2:26).

Prices fell when peace returned to America, but a generation later Napoleon's Continental system held out the promise of a similar scarcity in the absence of American competition. By the Napoleonic era, however, the Habsburg government, perhaps desperate to raise funds due to the extraordinary pressures of war with revolutionary France, had raised the export tax roughly tenfold. At these prices, Hungarian tobacco ceased to be competitive in European export markets (Orosz 2:26). ${ }^{2}$ As Hungarian reformer Gregor Berzeviczy (35) wrote with frustration in a work on Hungary's Industry and Commerce,

If Hungary were able to export its tobacco freely, it would be able to compete with American tobacco, which has become practically universal in northern Europe. The English-American war, which interrupted the supply of American tobacco to Europe, would have been an opportune time for expanding this industry and commerce. Apaldo used this opportunity, but not Hungary. [Wenn Ungarn die freie Ausfuhr seines Tabacks hätte, so würde es in der Concurenz den amerikanischen Tabak, der in das nördliche Europa beinah ausschließend geführt wird, verdrängen. Bey Gelegenheit des englischamerikanischen Krieges, während welchem die Einfuhr des amerkianischen Tabaks nach Europa gehindert war, würde es der günstige Zeitpunkt geswesen seyn, diesen Industrieund Comerzzweig viel zu vergrößern. Diesen Umstand hat zwar die Apaldo, aber Ungarn wenig benützt].

Hungarian dreams of earning fabulous tobacco fortunes lived on after Napoleon's downfall. In 1817, the journal Ungarische Miscellen suggested hopefully that neighbouring countries would prefer to buy from Hungary "than from far distant

\footnotetext{
${ }^{2}$ The export tax fluctuated from 1-2 florins a centner; a florin was then worth 20 kreuzer.
} 
Maxwell, Alexander. "Tobacco as Cultural Signifier: A Cultural History of Masculinity and Nationality in Habsburg Hungary." AHEA: E-journal of the American Hungarian Educators Association, Volume 5 (2012): http://ahea.net/e-journal/volume-5-2012

American peoples" [als von den entfernten amerikanischen Völker] (Ungarische

Miscellen 78). It asked "his imperial and royal Majesty ... to graciously allow the free export of tobacco" [seine k. k. Majestät zu bitten, daß sie die freye Ausfuhr des Tabaks... gnädigt erlauben möge] (Ungarische Miscellen 84). Such pleas, however, did little to change Habsburg policy.

Frustrations over the tobacco export tax meant that Hungarian farmers and landowners frequently blamed any financial difficulties on imperial tax policy. Hungarian producers also thought that the Empire would increase its own revenues through a lower tax, believing that a lower tax would enable a large increase in the total volume of trade. Such reasoning made the imperial government appear not only greedy but incompetent. The Austrian tobacco monopoly, and its control over tobacco exports from the monarchy, had thus become a significant Hungarian grievance against the Habsburg monarch by the early nineteenth century.

Political tensions over tobacco policy made the smoking of tobacco a patriotic act in Hungary. An 1827 poem by Károly Kisfaludy (67-9), for example, used smoking as a metaphor of national solidarity:

De ha jö egy lelkes Magyar, Szivcserére kész velem,

Szembe nem méz, hátul nem mar, Nyiltan leli kebelem;

Sokat ugyan nem adhatok, Legfelebb egy dalt mondhatok:

De felcsapván jobbjával, Megkinálom pipával.
But when an Hungarian calls, Spirited, to have a chat,

No honeyed words no knife in back, Open he will find my heart;

Much, in truth, I cannot give him, Just a simple verse at most:

But I shake his hand with pleasure, And offer him a pipe to smoke.

Kisfaludy's poem treats shared tobacco as a symbol of unity between himself and a fellow patriot (literally, an "enthusiastic Hungarian [lelkes Magyar]"), but also made clear that this solidarity only extended to properly masculine men:

Ha egy úrfi, pézsmán hízott
Felfürtözött üres kép,
Szük elméjü, de elbízott,
Nagy gögösen hozzám lép,
Magát, javát fitogtatja,
Drága idöm elragadja:
Fegyver leszen pipámból,
Kifüstölöm szobámból.

Ha egy úrfi, pézsmán hízott

Nagy gögösen hozzám lép,

Drága id"om elragadja:

Kifüstölöm szobámból.

\footnotetext{
When a dandy, reeking musky, Hair in ringlets, vacant face,

Mind a blank yet brazen sanguine, Comes to see me filled with pride,

Brags about himself, his fortune, Wasting thus my treasured time:

Then my pipe becomes a weapon, And I smoke him from my room.
}

Kisfaludy's poem suggests that by 1827 tobacco patriotism had transcended economic considerations: the act of smoking had itself become patriotic.

The year 1827 also proved a watershed for Hungarian patriotic smoking when count István Széchenyi, popularly known as "the greatest Hungarian" [legnagyobb Magyar] and the central figure in this period of Hungarian history, ${ }^{3}$ opened the Pest Casino. The term "casino" may mislead contemporary anglophones: Széchenyi was not

\footnotetext{
${ }^{3}$ On Széchenyi's life and role in Hungarian history, see Barany (1968); on Széchenyi's construction projects, see Zelovich (1999); on Széchenyi's legacy, see Vermes (1995).
} 
Maxwell, Alexander. "Tobacco as Cultural Signifier: A Cultural History of Masculinity and Nationality in Habsburg Hungary." AHEA: E-journal of the American Hungarian Educators Association, Volume 5 (2012): http://ahea.net/e-journal/volume-5-2012

trying to make a profit from gamblers, but to create a social institution where Hungarian elites could exchange ideas. He drew his inspiration from English gentlemen's clubs, which he had admiringly visited while travelling in the United Kingdom (Tóth 169-70), and was particularly interested to bring the Hungarian aristocracy in contact with venture capitalism, which he explained in his influential Hitel (1830), which quickly appeared in German translation (Vojdisek 1830; on the influence of this work, see Dénes 173, 79; Vermes 157-67; Barany 39-40, 212-13). In his diary, Széchenyi described the institution as a place where "One could smoke a pipe, exchange ideas, read different papers, and if one would stay longer, one could even have supper" (Viszota 3:xlii, Barany 168).

Széchenyi's casino became a national phenomenon; the best proof of its success lies in its imitators: six years later, nearly 30 Hungarian casinos had been founded (Goda 250).

By the nineteenth century, Hungarians also smoked in unusual quantity. Exporters unable to compete in international markets may have dumped their product on the domestic market at low prices, alternatively Hungarians may have felt it patriotic to support struggling domestic producers. Whatever the cause, foreign visitors often remarked on how much Hungarians smoked. English doctor Richard Bright, who visited Hungary in 1812, was shown around a tobacco factory as a tourist attraction, and reported that "almost the whole male population are constantly consuming this article" $(209,598)$. Michael Quin, who rode the Danube steamboats in the 1830s, described Hungarian smoking as "the most potent, and to a non-smoker the most offensive, I believe, that has yet been manufactured" (35). English author John Paget, who later married a Hungarian lady and settled in Transylvania (Kádár 9-20), characterized Hungarian smoking as excessive even by central European standards:

If I complained that the Casino of Pest was invaded by the pipe, what shall I say of that of Klausenburg [Cluj, in modern Romania]? Its air is one dense cloud of smoke, and it is easy to detect any one who has been there by the smell of his clothes for some time after. Such a smoking nation as this I never saw; the Germans are novices to them. Reading, walking, or riding, idling or at work, they are never without the pipe. Even swimming, I have seen a man puffing away quite contentedly. (2:509-10)

The only Hungarian males who could honourably refrain from smoking, it seems, were children. An 1844 poem about smoking, written by Pál Székács but published in the patriotic newspaper Pesti Divatlap, urged young boys to refrain from smoking: "Wait, young lad, don't take up the pipe, you can do so when you are a man" [Varj, fiu, még ne pipázz, majd ráérsz férfi korodban] (Székács 331). Insofar as smoking symbolized Hungarian patriotism, Paget's account hints at the increasingly nationalistic atmosphere in Hungary. Consumption statistics, furthermore, show that Hungarians consistently consumed more tobacco per capita than Austrians (Sandgruber a 213).

Tensions between Hungary and the Habsburg monarchy mounted in the 1830s and 1840s, and Hungarian reformers compiled an ever-lengthening list of grievances

\footnotetext{
4 The reference to German smoking reflects a commonly-held English belief that Germans were particularly heavy smokers. One physiologist wrote that "Germans sit for hours in low crowded rooms, so dense with tobacco-smoke that you cannot recognize your friends; and so vitiated is the atmosphere by the compound of breath, bad tobacco, exhalations of organic putrefiable matters, and an iron stove, that at first it seems impossible for you to breathe in it." See Lewis 373.
} 
Maxwell, Alexander. "Tobacco as Cultural Signifier: A Cultural History of Masculinity and Nationality in Habsburg Hungary." AHEA: E-journal of the American Hungarian Educators Association, Volume 5 (2012): http://ahea.net/e-journal/volume-5-2012

against the monarchy (Knatchbull-Hugessen 1:275-80; Szekfü 1926). Fears that Hungary would fall under the Austrian tobacco monopoly persisted throughout the so-called Reform Era, roughly 1825-1848 (Horváth 2:331), though the language of government administration eventually eclipsed tobacco as the main national issue in Hungarian political life (Deme 629; Maxwell a 385-414; Varga 1993). When Revolution broke out in March 1848, however, the new Hungarian government quickly closed the Pest office of the Habsburg monopoly (Der Humorist 1848).

While the 1848 Revolution should not be seen primarily as a tobacco-related event, it did bring tobacco politics to considerable prominence in the Habsburg monarchy. Italians played a more important role in this process than Hungarians. The Habsburg state monopoly did not enjoy popular support in Milan, and Italian leaders frustrated with Habsburg rule organized a popular boycott of imperial tobacco. To enforce the boycott, Italian patriots began confronting pedestrians who dared to smoke in public. The commander of Austrian forces in northern Italy, Field-Marshall Joseph Radetzky, rightly saw the boycott as an attack "against the state revenue, against an article of commerce which the state alone produces and sells!" Though urged to show discretion, Radetzky declared confrontationally that he "would not recognize or tolerate any secret tribunal which attacked and insulted peaceful smokers on the street" (Sked 107, 115; Ginsborg 515), and in February 1848 ordered plain-clothed soldiers to smoke on the street. He hoped to encourage would-be smokers to smoke with confidence, but also to arrest any patriots who attempted to enforce the patriotic boycott. An Italian caricaturist found Radetzky's tactics provocative, and depicted him giving a line of cigarwielding Croatian soldiers the order to "fire!" One of the soldiers responds: "Just emperor, just general! You order your soldiers to light cigars, but all of Austria will go up in smoke" [Prafe Imperator! Prafe gheneral! Ti far fumate tua Militar. Tutte austria va per fume]. (Chiesa). The satirist proved prophetic. Radetzky's orders led to scuffles, and the resulting protests led to Revolution in Italy.

The Hungarian revolution proved even more dramatic than the Italian. Initially successful, the Hungarian revolutionary government provoked rebellion in the Croatian and Romanian regions of the country. When Austrian forces attempted to restore imperial authority, the revolutionary government declared that the Habsburg claim to the Hungarian crown was no longer valid. Imperial and revolutionary armies fought a series of pitched battles in 1848 and 1849, and while the Hungarian armies eventually met with total defeat, they won their share of battles (Deák 1979). No less a revolutionary than Karl Marx expressed admiration for their revolutionary potential (Frank).

The drama of revolutionary war pushed agricultural policy from centre stage, yet tobacco still played a central role in the dramatic and highly symbolic death of at least one Hungarian officer. In 1849, as Austrian armies approached Budapest, Hungarian revolutionaries mined the first and then only permanent bridge over the Danube, the celebrated Chain Bridge [lánchíd], which had just been completed that same year thanks to Széchenyi's tireless work. ${ }^{5}$ When the imperial forces overcame the Hungarian defences, the colonel charged with holding the chain bridge, "in order to die with éclat

\footnotetext{
${ }^{5}$ As a testament to the centrality of the Chain Bridge in subsequent Hungarian memory, consider that Géza Bereményi titled his 2002 film biography of Széchenyi Hídember [Bridgeman].
} 
Maxwell, Alexander. "Tobacco as Cultural Signifier: A Cultural History of Masculinity and Nationality in Habsburg Hungary." AHEA: E-journal of the American Hungarian Educators Association, Volume 5 (2012): http://ahea.net/e-journal/volume-5-2012

when all was lost, ... flung his cigar into a powder-barrel which communicated with the mine beneath the bridge. ... The body of the Colonel was found burnt to a cinder" (Schlesinger 1:259; Wenkstem 167). While this quintessential Hungarian martyrdom demonstrated the courage and bravery Hungarian patriots showed during the revolution, the colonel's death also symbolized the revolution in its futility: the Chain Bridge survived and fell into Austrian hands, along with the country as a whole.

On 29 November 1850, after the defeat of the Hungarian revolution, Habsburg emperor Franz-Joseph (ruled 1848-1916) abolished Hungary's constitutional existence and attempted to rule the kingdom as a series of distinct provinces. As concerns tobacco, this period of "neo-absolutism" (1850-1859) saw the hated Austrian state monopoly extend into Hungary. The monopoly's director, Baron Georg von Plenker, admitted that the organization had "met with great opposition at first," but claimed in an American economic journal that "the system is now thoroughly established, and is in a flourishing condition," not least because "prices paid for the best quality of tobacco at the monopoly receiving warehouses have been considerably raised ... to induce the planter to pay more attention to cultivation" (von Plenker 150, 155). A British diplomat stationed in the Empire, however, drew more cynical conclusions about the monopoly's purchasing practices:

\begin{abstract}
After harvest the Government takes the whole crop at a fixed price for each of the three qualities into which tobacco is divided. It is said that this classification into "best, middling and common" is very arbitrarily and unjustly applied. The Government also reserve for themselves the right of rejecting such of the produce as they consider unfit for use, and I was informed that on this plea large quantities are destroyed without payment by the government when they find the yield of the year to be inconveniently abundant. (Fane 1859)
\end{abstract}

Several Hungarian producers preferred to burn their crops rather than sell under such conditions. One peasant found himself prosecuted for vandalism, though he successfully argued in court that the crop was private property, and that he had the right to dispose of it as he wished (Brace 226).

Whether from avarice or the desire to punish rebellious Hungary, the government had apparently used the tobacco monopoly as a means of punitive taxation. Previously, Hungarian producers would negotiate a price with various trading companies without restriction, but now the Habsburg monopoly destroyed the producer's ability to bargain. A Hungarian farmer in Heves county estimated that the market value of a centner of tobacco was around 40 gulden, but the state monopoly would only pay 7 to 12 gulden. To add insult to injury, the government sought further profits from Hungarian consumers: the same farmer estimated that he would need 70 gulden to repurchase the same tobacco for his private use (Brace 368). One might be sceptical of Brace's figures: he had become carried away with enthusiasm for the Hungarian cause, and his brief imprisonment did not endear him to the Habsburg dynasty. Brace's informant, furthermore, may also have exaggerated Austrian injustices for the foreign visitor. Yet imperial authorities themselves acknowledged the unpopularity of the monopoly. In 1859, Count Alexander Hübner, an Austrian diplomat, listed the tobacco monopoly as one of Hungary's top three grievances under Habsburg rule: "The average Hungarian would only be satisfied with a 
Maxwell, Alexander. "Tobacco as Cultural Signifier: A Cultural History of Masculinity and Nationality in Habsburg Hungary." AHEA: E-journal of the American Hungarian Educators Association, Volume 5 (2012): http://ahea.net/e-journal/volume-5-2012

constitution for Hungary, lowering of taxes, the lifting of the tobacco monopoly, and the introduction of Hungarian as the language of administration" (Hübner 1:115).

Hungarian patriots, following the Italian example, declared a boycott of the Austrian tobacco monopoly. Brace met many Hungarians that refused to smoke "Imperial tobacco," though he also doubted their ability to withstand temptation (Brace 103, 370). When Sándor Mednyánszky offered an Austrian cigar to a "stalwart elderly Hungarian, dressed in a bunda," whose son had lost an arm fighting in the Hungarian army, the offer was refused with the following explanation:

"It was not from any wish to offend you that I declined, sir," a cloud suddenly
overcastting his honest features, "but since the Austrians have forbidden us the free use
of our own tobacco, unless we sell it at a very low price to them and buy it back for six
times that amount, we have given up both the growth and the use of it in our
community."

Mednyánszky, as it happened, already knew about the Hungarian demonstration against the monopoly, and had only offered the cigar after observing the elderly Hungarian smoking a pipe. Mednyánszky had assumed that a smoking Hungarian was not participating in the boycott. It transpired that the elderly gentleman had filled his pipe not with tobacco, but with "vine-leaves steeped in a decoration of plums, a poor substitute indeed for tobacco, but still they give out smoke" (Mednyánszky 63).

Hungarians did, however, show great eagerness to smoke wherever Habsburg authorities sought to forbid it. An anonymous English traveller on the Danube steamboat reported in 1855 that "the flaming announcement over the door of this little cabin, in four languages, and as many different coloured letters, that smoking was positively forbidden, seemed but to encourage our passengers in this annoying luxury" (Stick and Carpet Bag 47). In this regard, Hungarians may have followed the example of German rather than Italian radicals: during the 1848 revolution, several German patriots had demanded that commoners gain the right to smoke in public parks (Sandgruber b 141). The anonymous English traveller of 1855, meanwhile, found Hungarian smoking as difficult to bear as had his predecessors: "every night, immediately after tea, there was a general drawing forth of long pipes and short pipes, and cigars stuck into amber holders, which soon produced an atmosphere that would have resurrected a smoked herring" (Stick and Carpet Bag 47). Such comments suggest that Hungarians did indeed smoke in quantities and settings exceptional by contemporary European standards.

In the decade of Habsburg neo-absolutism, the Hungarian tobacco industry contracted dramatically, whether due to Austrian mismanagement, patriotic boycott, unfavourable weather conditions, or other factors. When Hungarian deputies to the 1860 Austrian Reichsrat discussed the tobacco sector, they worked from the assumption that Hungary's annual tobacco exports had fallen two-thirds since 1848, from 150,000 to 50,000 centner (Silvestri 636). Several also expressed concern for the relative quality of Hungarian tobacco (Silvestri 629-33, 636-37; on numerous failed attempts to introduce American tobacco seeds to Hungary, see Hitz and Huber 59-60; "Wiener Stadtpost," Der Humorist 1853 143). Such considerations ultimately discredited the idea of a Hungarian tobacco monopoly even in Austrian eyes. 
Maxwell, Alexander. "Tobacco as Cultural Signifier: A Cultural History of Masculinity and Nationality in Habsburg Hungary." AHEA: E-journal of the American Hungarian Educators Association, Volume 5 (2012): http://ahea.net/e-journal/volume-5-2012

Franz-Joseph eventually abandoned neo-absolutism and gave up his attempt to incorporate Hungary into a unitary Empire. In 1859, military setbacks in northern Italy led to a period of constitutional experimentation (Kann 1950) that culminated in the famous Ausgleich or "Compromise" of 1867 (Tihany 1969, 114-38; Wynne 1968, 189214; Vantuch and Holotík 1971; on the economic dimensions of the Ausgleich, see Matlekovits 1898 17-27; for period discussions from a Hungarian and German national perspective, see Andrássy 1897, Friedjung 1877). As the Austrian Empire became the Austro-Hungarian Empire, the Hungarian parliament gained the ability to devise its own policies related to tobacco industries. Tobacco industries stopped generating Hungarian nationalism after 1867.

After the Ausgleich, however, Hungarian cigars remained potent national symbols in Hungary. The Hungarian parliament building, completed in 1896, forbade smoking in the debating chambers, yet paid deference to the patriotic leaf by including numbered brass cigar-holders in the ancillary hallways (see figure 1). Berkeley Smith, visiting Budapest in 1903, observed "all the respectable heads of political Hungary ... smoking and chatting before the final bell rang to announce the session," and when parliament adjourned, found that "fresh cigars are lighted, stories are told" $(88,95)$.

Figure 1: Cigar Holders in the Hungarian Parliament (Coleman)

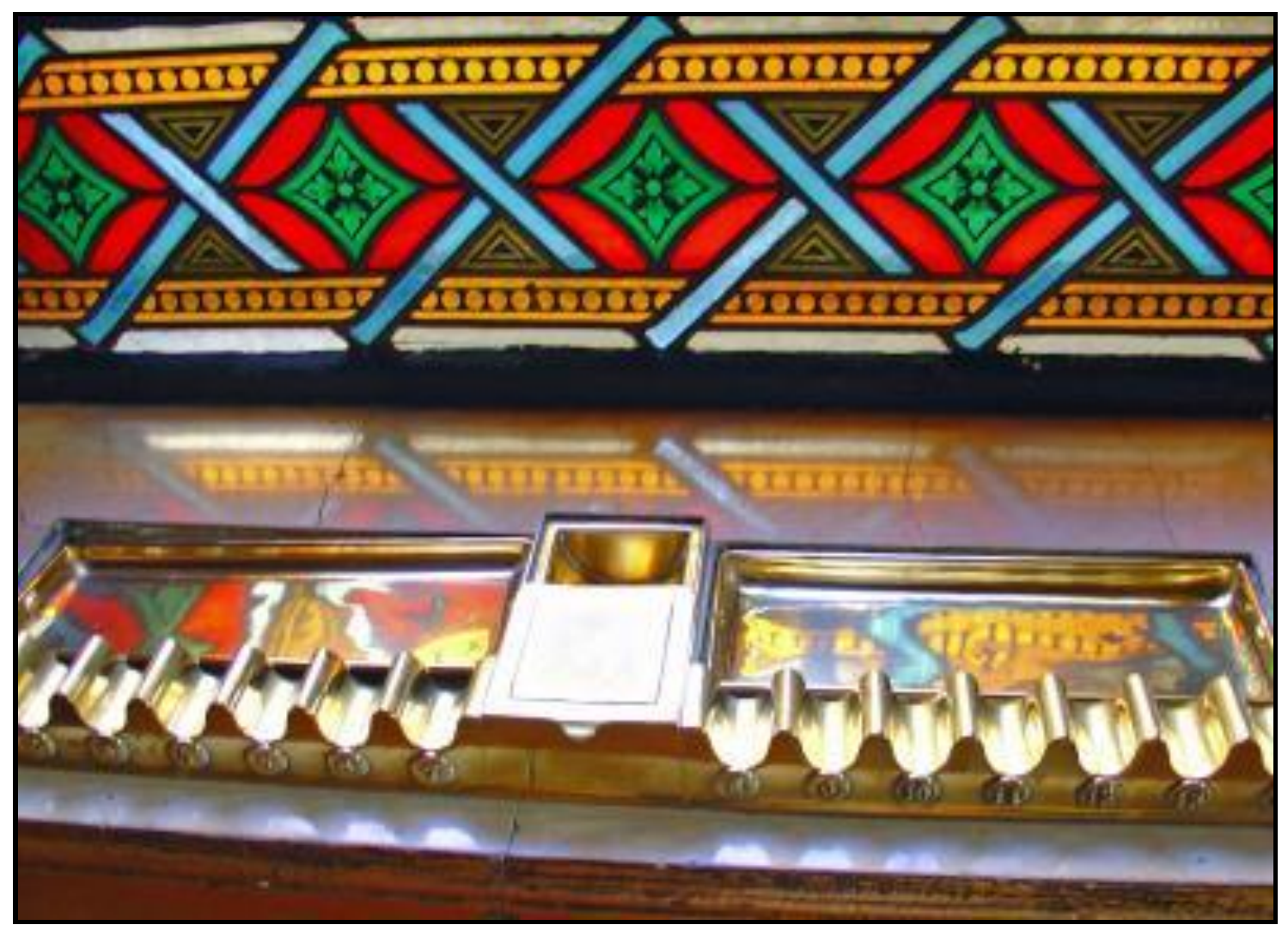

Hungarian novelists in post-Ausgleich Hungary also treated smoking as a metaphor of solidarity and contemplation. A character in Kálmán Mikszáth’s short story 
Maxwell, Alexander. "Tobacco as Cultural Signifier: A Cultural History of Masculinity and Nationality in Habsburg Hungary." AHEA: E-journal of the American Hungarian Educators Association, Volume 5 (2012): http://ahea.net/e-journal/volume-5-2012

"Prakovsky, a siket kovács [Prakovsky, the Deaf Blacksmith]" (a 95) needs his pipe to tell a story. Mikszáth also used tobacco smoking to symbolize the undertaking of a common endeavour: sly schemers in his novel Különös házasság [Strange Marriage] smoke to discuss their intrigues: as one says to another, "It'll be much nicer to discuss my plan over a pipe of tobacco" [gyújts rá, öcskös, pipafüst mellett könnyebben megbeszélhetjük azt a szép plánumot]. (Mikszáth b 143).

As a national symbol, tobacco smoking marked the patriot with other social variables. Hungarian smoking transcended ethnic differences, spreading beyond ethnic Hungarians to non-Magyar citizens of the Hungarian kingdom. In Croatia, then nominally under Hungarian jurisdiction though enjoying considerable autonomy, smoking also became an important symbol. One 1913 postcard depicted a young Croat, perhaps four or five years old, wearing Croatian national costume, holding a pipe, and proclaiming "I am a Croat and smoke well" (Ja sam Hrvat dušam ljefom). A short story by Croatian author Antun Matoš, furthermore, suggests that Croatian patriots developed their own tobacco boycott against foreign tobacco: Matoš described a household "in which only Croatian (i.e. Bosno-Hercegovian) tobacco was smoked" [U njegovoj se kući puši samo hrvatski, to jest bosanskohercegovački duhan] (Matoš 113).

Insofar as smoking differentiated Hungarians from non-Hungarian others, Austrians, typically understood as "Germans," formed the main the target of exclusion. Pipes and cigars featured prominently in Hungarian satire. An 1861 caricature titled from Bolond Miska depicted a Hungarian and a German in conversation; the Hungarian smoked a cigar labelled "1848," while the German holds an unlit cigar labelled "constitution." When the Hungarian asks "his Viennese cousin" why he does not smoke, the German answers that he lacks fire, a pun on Vienna's putative lack of revolutionary ardour (see figure 2).

Figure 2: "The Stogies" - A Hungarian and German in Bolond Miska (16). 
Maxwell, Alexander. "Tobacco as Cultural Signifier: A Cultural History of Masculinity and Nationality in Habsburg Hungary." AHEA: E-journal of the American Hungarian Educators Association, Volume 5 (2012): http://ahea.net/e-journal/volume-5-2012

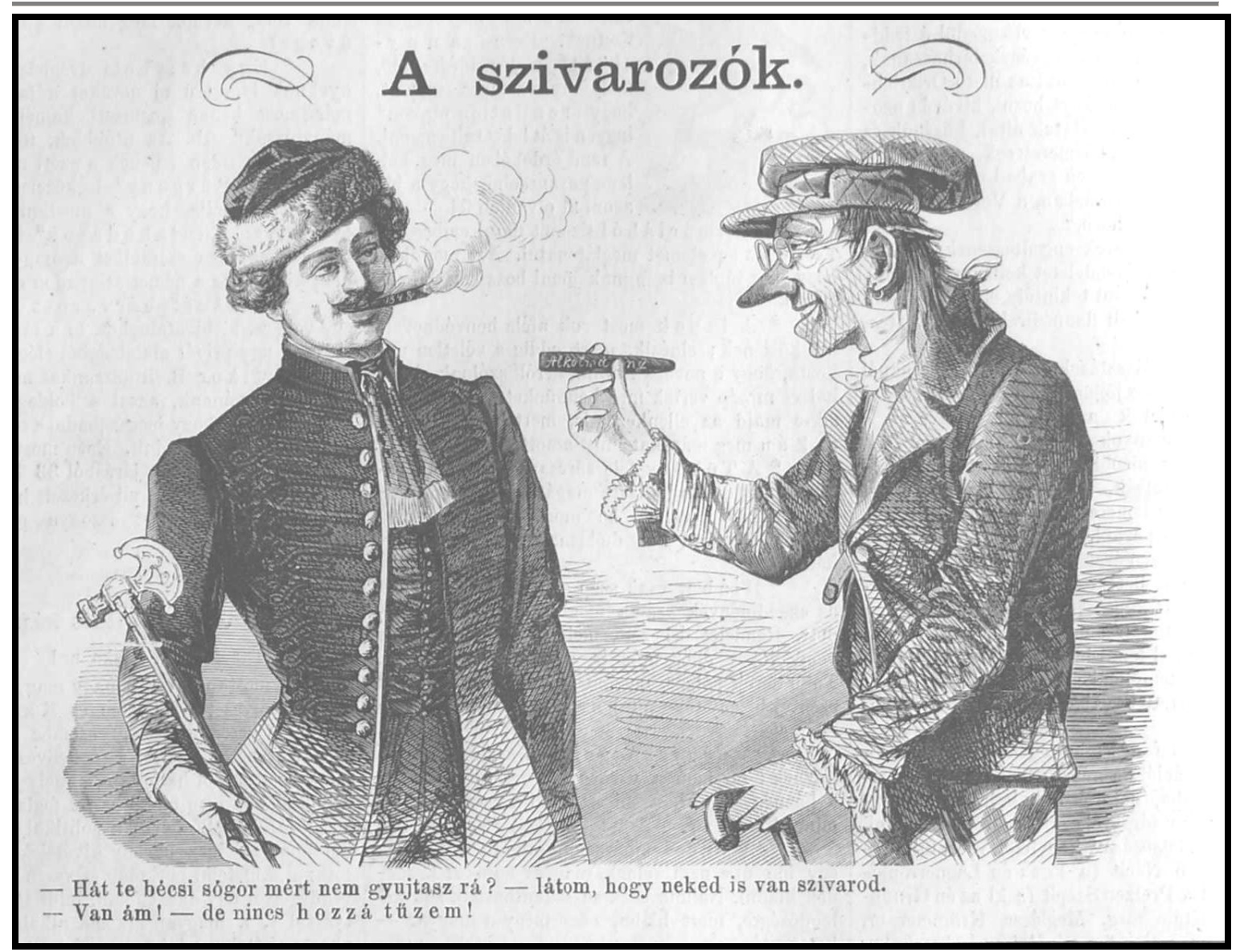

- My Viennese cousin, why don't you smoke? - I see that you have a cigar.

- I do, but I don't have any fire!

Hungarian tobacco patriotism also transcended class barriers inside Hungary. Several Anglophone visitors describe smoking peasants, and German traveller Jozef Martin $(157,653)$ reported that peasants listened to stories "sometimes lying flat, some sitting, often filling the short pipe," though note that these particular peasants were ethnic Romanians. Nevertheless, the Hungarian nobility successfully made its own style of smoking the most characteristically national. To smoke in the manner that a British foreign correspondent described in 1866, for example, would require the assistance of a personal servant: "some enthusiasts have a lighted pipe put into their mouths before they wake in the morning, so as to rise with the delicious flavour already produced" (The Cornhill Magazine 569). Hungarian noblemen also showed the privilege of their estate by smoking wherever they wished. Arthur Patterson (1:335) reported that

In the villages proclamations are stuck up forbidding smoking in the streets for fear of the straw-thatched cottages catching fire. Yet the 'gentlemen' may be seen lighting their pipes there explaining to the stranger as they do so that 'the laws are made for the peasants.' 
Maxwell, Alexander. "Tobacco as Cultural Signifier: A Cultural History of Masculinity and Nationality in Habsburg Hungary." AHEA: E-journal of the American Hungarian Educators Association, Volume 5 (2012): http://ahea.net/e-journal/volume-5-2012

Modern ethnographer László Kürti (b 81) concluded that "the question of who is a proper Hungarian or Magyar was embedded in the status quo of the nobility, its historic and legal rights, and in its values and lifestyles." Hungarian smoking fits Kürti's analysis.

One important segment of Hungarian society, however, did not share in the social solidarity generated through shared tobacco consumption: women. In the nineteenth century, smoking was a masculine habit, and Hungarian women, as a rule, abstained. The aforementioned Paget reported that Hungarian ladies positively disliked smoking: "I never knew a lady who did not dislike this custom; but they commonly excuse it by the plea that they could not keep the gentlemen with them if they did not yield to it" (2:511). Exuberant smoking, furthermore, could force women out of public places, much as Kisfaludy had banished effeminate fops. Paget (1:271-72) experienced this situation firsthand while visiting Balatonfüred:

Before the ladies had finished supper the gentlemen had already begun their pipes, and the whole room was soon in a cloud of smoke. As soon as the music struck up, a scene of such riot commenced - some were dancing, some singing, others smoking and applauding - that I was heartily glad when the countess B- declared it was no longer to be borne, and left the room, followed by the whole party of ladies.

When Paget argued to the countess and the other ladies that "it only depended on themselves to banish smoking and such abominations from their drawing rooms whenever they pleased," they told him that Hungarian men "prefer their pipes to our drawing rooms at any time; besides the woman who should attempt such a thing would be exposed to neglect and insult of every kind" (1:272-73). If Hungarian nobles treated smoking as a metaphor for their national rights, those rights included masculine privilege over women and, perhaps, effeminate men.

Smoking even enabled male commoners to assert their status over elite women. Paget wrote that "a coachman thinks it a great hardship if he may not smoke as he is driving a carriage, although it may happen that the smoke blows directly into the face of his mistress" (2:510). Travelling in Hungary half a century later, Nina Mazuchelli $(1: 104)$ confirmed Paget's observations, reporting that her coachman smoked "every mortal moment." Even when a heavy rainstorm finally extinguished his pipe, Mazuchelli observed that her coachman kept his pipe in his mouth; she believed that he was "pretending to smoke."

The link between masculine privilege and national symbolism obviously lends itself to feminist analysis. Carole Pateman (a 78), in her celebrated if somewhat Freudian study of social contract theory, has suggested that the "national brotherhood [fraternité]" of the French Revolution had little to offer women:

A very nice conjuring trick has been performed so that one kinship term, fraternity, is held to be a metaphor for the universal bonds of humankind, for community, solidarity, or fellowship. [...] Almost no one - except some feminists - is willing to admit that fraternity means what it says: the brotherhood of men.

Pateman (b 50) also suggests that patriots see women as part of the "fraternal body politic" only insofar as they have a relationship with a national man. Women can be 
Maxwell, Alexander. "Tobacco as Cultural Signifier: A Cultural History of Masculinity and Nationality in Habsburg Hungary." AHEA: E-journal of the American Hungarian Educators Association, Volume 5 (2012): http://ahea.net/e-journal/volume-5-2012

patriots as mothers, daughters, wives, or objects of male erotic desire (Maxwell b 41333). Yet women as women, much like Marx's proletariat, have no fatherland. ${ }^{6}$

The highly gendered quality of Hungarian patriotic smoking apparently supports

Pateman's ideas. Indeed, it seems that Pateman did not herself appreciate the depth of her own insights. Pateman analyzed contract theorists, legal structures, and the "civic nations" they imply; she did not consider "ethnic nations" or, perhaps more precisely, communities imagined in cultural or ethnic terms. Sifting through various cultural artefacts suggests that Hungarian patriotic smoking articulated a consistent and coherent worldview, but no political philosopher ever codified it as a formal ideology.

Pateman's gendered analysis, furthermore, applies to other symbols of Hungarian nationalism, such as the Hungarian moustache. A wide variety of cultural evidence suggests that Hungarians saw moustaches as national icons. Paget found that, at a school for the deaf and dumb, the concept "'Hungarian' is expressed by touching the upper lip, indicating a mustache" (1:321), and ultimately concluded that "in no country of Europe is the mustache held in such respect as in Hungary" (1:463). One hapless hussar accidentally burned his moustache off while smoking in bed, and felt compelled to use hair extensions (The Anglo-American Magazine 887). When Dr. Dumany, the cleanshaven hero of Mór Jókai's 1890 novel Nincsen ördög [“There is no Devil," cited in English from Steinitz's rather free 1890 translation, Dr. Dumany's Wife], attempts to speak at a political meeting, he is asked: "If you are a Hungarian, sir, as you claim, where is your moustache?" [Ha magyar az úr, hová lett a bajusza?] (111). Later in the novel, when Dumany starts to grow a moustache for his abortive political career, a supporter praises his stubble:

\begin{abstract}
his sprouting moustache and beard are a token of patriotic zeal, and a sacrifice upon the altar of national idiosyncrasy. Henceforth he will be known as a Hungarian in his appearance also, and nobody will be justified in calling him an Austrian. [Fogadása tartja, hogy jövőre szakállt, bajuszt ereszt. A hazáért és a vallásért hozza az áldozatot. Hogy a jövő választásnál ne mondhassák róla, hogy bécsi német]. (156)
\end{abstract}

The national symbolism of facial hair, as that of tobacco, also extended down the social hierarchy. During the Bach regime, Brace (112) met a peasant who expressed his hopes for Kossuth's eventual victory by swearing "not to cut my beard till he returns!" The moustache also transcended Hungary's ethnic divisions, even if different styles of moustache became associated with different nationalities (Herman 1906 30-33). For example, one Austrian officer observed that Transylvanian Székely (also known as Szeklers) wore "a long moustache, not closely twisted up to a point, like that of the Magyars, but hanging loosely down" ("Baron W" 25).

Moustaches, like cigars, implied not only Hungarian nationality but masculinity (Maxwell c 180-204). Hungarian proverbs may have considered "a Hungarian without a moustache" as unnatural a state of affairs as "a king without a country" or "a priest without a book" [Eb a Magyar bajusz nélkül, Eb a király ország nélkül, Eb a pap könyv nélkül] (Ballagi 93-94), yet they also insisted that "moustache and beard only concern

\footnotetext{
${ }^{6}$ Though generally translated into English as “The working men have no country," Marx's original German reads "Die Arbeiter haben kein Vaterland."
} 
Maxwell, Alexander. "Tobacco as Cultural Signifier: A Cultural History of Masculinity and Nationality in Habsburg Hungary." AHEA: E-journal of the American Hungarian Educators Association, Volume 5 (2012): http://ahea.net/e-journal/volume-5-2012

men" [Bajusz a szakáll férfiembert illet] (Ballagi 31). László Kürti (a 155) describes a Hungarian folk tale in which a woman grows a moustache to avoid an unwanted marriage. By growing a moustache, the protagonist of this folk tale might symbolically claim membership in the national community in her own right, but ceases to be an object of erotic desire. The Patemanian symbolism is hard to ignore.

Women who attempted to join the national community of smoking Hungarians similarly lost their desirability, and additionally their respectability. In 1912, Svetozar Hurban-Vajanský, a conservative thinker from northern Hungary, denounced modern women who "starve themselves to be thin and to look like men, wear disgusting American shoes, smoke primitive cigars, waste time with empty philosophizing and engage in sex. They agitate for feminism, but give rise to masculinity" (Weber 55). If, as Richard Reed (93) put it, "The cigar as object reaffirms a man's power over other people as both class and sexual objects," then women's exclusion from this masculine national symbol reinforced a masculine understanding of the nation (Brändli 1996 83-109).

Hungarian noblemen did not, of course, see themselves as oppressors of women. Several refrained from smoking in the presence of women out of chivalry. In the novels of Mór Jókai, for instance, a gallant unwillingness to smoke around women reliably distinguishes heroes from villains. When asked to visit a countess in her chambers, the narrator of one novel relates: "I had to obey her polite commands, so, throwing away my cigar, I bowed [...] and followed the lead of the valet" [Siettem eldobni a szivaromat, $s$ hagytam magamat a grófnő budoárjába átvezettetni]. (Jókai 47). Later in the novel, when the villain Siegfried blows cigarette smoke out a window in consideration of his aunt, the hero thinks to himself "it would have been more considerate still if he had not smoked at all” (Jókai 227). Széchenyi, furthermore, feared that excessive smoking might alienate Hungarian noblewomen from the national movement.

If we wish our ladies to become Hungarianized, then let us make what is Hungarian acceptable, pleasing. [...] We cannot expect that our beauties would love to be in the company of a patriot, who, I daresay, would visit in greasy boots and fill up the house with pipe fumes (Széchenyi 67-69; Lampland 293; Paget 204-228).

Intermittent gallantry did not, however, mitigate the masculinism of Hungarian patriotic symbolism. Considerate men might, if they chose, refrain from smoking around women, much as they might give charity. But if men insisted on smoking, as Paget observed in Balatonfüred, women had no option but to retire.

The cultural study of Hungarian masculinity, in short, shows that Hungarian national symbols also signified masculine privilege. Tobacco in particular conflated patriotism and manliness. If due attention is paid to what Slavoj Žižek called "the gap that separates penis-as-organ from phallus-as-signifier" (88) then the Hungarian pipe, and particularly the Hungarian cigar, might be seen as a phallus: a cherished symbol of masculine potency. While Hungarians of all ethnicities theoretically had access to it, only powerful men from the social elite could properly wield and enjoy it. Women, by contrast, had no access to this symbol, and unsexed themselves if they strove to obtain it. Despite Sigmund Freud's possibly apocryphal comment about his Viennese smokes (Keyes a 246; Keyes b 29), the Hungarian cigar was evidently more than just a cigar. 

Habsburg Hungary." AHEA: E-journal of the American Hungarian Educators Association, Volume 5 (2012): http://ahea.net/e-journal/volume-5-2012

\section{Works Cited}

Andrássy, Gyula. 1897. Ungarns Ausgleich mit Österreich vom Jahre 1868 [Hungary's Compromise with Austria from the Year 1868], Leipzig: Duncker and Humblot. Anonymous. 1817. "Über die Beförderung des ungarischen Commerzes [On Promoting Hungarian Commerce].” Ungarische Miscellen [Hungarian Miscellany], Volume 1 .

Anonymous. 1853. "Why Shave?” The Anglo-American Magazine 3.

Anonymous. 1855. Adventures with my Stick and Carpet Bag; or, What I saw in Austria and the East. London: James Blackwood.

Anonymous. 1861. "A szivarozók [Cigar-Smoking]." Bolond Miska [Silly Mike] 2:4.

Anonymous. 1866. "Transylvania.” The Cornhill Magazine 14: 567-85.

Anonymous. 1913. "Ja sam Hrvat dušam ljefom [I am a Croat and smoke well]" Postcard identified as "C.W.W., I IX 1913 ges. gesch," private collection.

Ballagi, Mór. 1855. Magyar példabeszédek. Pest: Gusztáv Heckenast.

Barany, George. 1968. Stephen Széchenyi and the Awakening of Hungarian Nationalism, 1791-1841. Princeton: Princeton University Press.

"Baron W." 1850. Scenes of the Civil War in Hungary, in 1848 and 1849: with the Personal Adventures of an Austrian Officer. Frederic Shoberl, trans. Philadelphia: E.H. Butler.

Benkó, Joseph. 1793. Közep-Ajtai Dohány [Central Ajta Tobacco]. Kolosvár: Márton.

Berzeviczy, Gregor von. 1802. Ungarns Industrie und Commerz [Hungary's Industry and Commerce]. Weimar: Gädicke.

Brace, Charles Loring. 1853. Hungary in 1851, with an Experience of the Austrian Police. New York: Scribner.

Brändli, Sabina. 1996. "Sie rauchen wie ein Mann, Madame, zur Ikonographie der rauchenden Frau im 19. und 20. Jahrhundert [You Smoke like a Man, Madame: On the Iconography of Smoking Women in the $19^{\text {th }}$ and $20^{\text {th }}$ Centuries]," Tabakfragen: Rauchen aus Kulturwissenschaftlicher Sicht [Tobacco Questions: Smoking from a Cultural Historical Perspective], Thomas Hengaitner and Christian Maria Merki, eds. Zurich: Chronos.

Bright, Richard. 1818. Travels from Vienna through Lower Hungary. Edinburgh: A. Constable and Company.

Chiesa, Gabriele. 1849. "A proposito dello sciopero del tabacco [On the Tobacco Strike]." Brescia nel 1849 [Brescia in 1849]. February 10, 2009: <http://www.brescialeonessa.it/xgiorni/ambiente/satira/index.htm>

Coleman, Dan. “Cigar Holders for Members Called In for a Vote.” June 15, 2005 : <http://www.pbase.com/dcoleman59/image/34576181/medium>

Deák, István. 1979. The Lawful Revolution: Louis Kossuth and the Hungarians, 1848-49. New York: Columbia University Press.

Deme, László. 1984. "Writers and Essayists and the Rise of Magyar Nationalism in the 1820s and 1830s." Slavic Review 43.4: 624-40.

Dénes, Iván Zoltán. 2006. Liberty and the Search for Identity. Budapest: CEU Press. Der Humorist. June 23, 1848. 12.150.

Der Humorist. February 13, 1853. "Wiener Stadtpost [Vienna City Bulletin]” 17.36. 
Maxwell, Alexander. "Tobacco as Cultural Signifier: A Cultural History of Masculinity and Nationality in Habsburg Hungary." AHEA: E-journal of the American Hungarian Educators Association, Volume 5 (2012): http://ahea.net/e-journal/volume-5-2012

Evans, Ifor. 1928. "Economic Aspects of Dualism in Austria-Hungary." Slavonic and East European Review 6.18: 529-42.

Mr. Fane to Lord J. Russel. December 3, 1859. British Documents on Foreign Affairs, The Habsburg Monarchy, 1859-1905. 1991. David Stevenson, ed. Arlington: University Publications of America.

Frank, Tibor. 1985. Marx és Kossuth [Marx and Kossuth]. Budapest: Magvető.

Friedjung, Heinrich 1877. Der Ausgleich mit Ungarn: Politische Studien über das Verhältnis Österreichs zu Ungarn und Deutschland [The Compromise with Hungary: Political Studies of Austria's Relationship to Hungary and Germany] Leipzig: Otto Wigand.

Ginsborg, Paul. 1974. "Peasants and Revolutionaries in Venice and the Veneto, 1848." The Historical Journal 7.3: 503-550.

Goda, Éva. 2001. “1848-49-es dokumentumok az egyesült Debreceni Polgári Casino-ban [1848-49 Documents from the Debrecen Civic Casino Association]," Magyar Könyvszemle [Hungarian Book Review], 117.2: 250.

Herman, Otto. 1906. “A Magyar bajusz (The Hungarian Moustache).” Magyar Nyelv [The Hungarian Language] 2.1.

Hitz, Harald and Hugo Huber. 1975. Geschichte der österreichischen Tabakregie, 17841834 [History of the Austrian Tobacco Monopoly, 1784-1834]. Vienna: Austrian Academy of Sciences.

Horváth, Michael. 1867. Fünfundzwanzig Jahre aus der Geschichte Ungarns (18231848) [Twenty-five years from the History of Hungary (1823-1848)]. Leipzig: Brockhaus.

Hübner, Alexander. 6 September 1859. "Letter to the Emperor." Graf Julius Andrássy, sein Leben und seine Zeit [Count Julius Andrássy, His Life and Times]. 1910. Eduard von Wertheimer. Stuttgart: Deutsche Verlags-Anstalt.

Hurban-Vajanský, Svetozar. 1912. "Feminizmus a Slovensko [Feminism and Slovakia]," Národnie Noviny.

Jókai, Mór. 1890/1. Nincen ördög [Dr. Dumany’s Wife]. F. Steinitz, trans. New York: Doubleday. A German version is also available: Ludwig Wechsler. 1891. Es Gibt Keinen Teufel. Berlin: Otto Janke.

Kádár, Judit. 1989. "Perspectives on Commercial and Political Relations between Britain and Hungary as seen by English Travelers in the 1850s." Hungarian Studies 5.1: 9-20.

Kann, Robert. 1950. The Multinational Empire: Nationalism and National Reform in the Habsburg Monarchy, Vol. 2: Empire Reform. New York: Columbia University Press.

Keyes, Ralph a. 1992. Nice Guys Finish Seventh: False Phrases, Spurious Sayings, and Familiar Misquotations. New York: HarperCollins.

Keyes, Ralph b. 2006. The Quote Verifier: Who Said What, Where, and When. London: St. Martin's Press.

Kisfaludy, Károly. 1859. "Pipadal [Pipe Song]." Minden Munkái [Complete Works]. Pest: Gusztáv Heckenast, 1:67-69. English translation from Stephen Pálffy. "In Praise of Pipe Smoking." March 15, 2005:

<http://www.users.zetnet.co.uk/spalffy/pipa.htm> 
Maxwell, Alexander. "Tobacco as Cultural Signifier: A Cultural History of Masculinity and Nationality in Habsburg Hungary." AHEA: E-journal of the American Hungarian Educators Association, Volume 5 (2012): http://ahea.net/e-journal/volume-5-2012

Knatchbull-Hugessen, Cecil Marcus. 1908. The Political Evolution of the Hungarian Nation. London: National Review Office.

Kürti, László a. 1999. "Eroticism, Sexuality and Gender Reversal in Hungarian Culture." Gender Reversals and Gender Cultures: Anthropological and Historical Perspectives. Sabrina Ramet, ed. London: Routledge.

Kürti, László b. 2001. The Remote Borderland: Transylvania in the Hungarian Imagination. Albany: SUNY Press.

Lampland, Martha. 1994. "Family Portraits: Gendered Images of the Nation in Nineteenth-Century Hungary." East European Politics and Societies 8.2: 287316.

Lewis, George Henry. 1859. The Physiology of Common Life. Edinburgh: William Blackwood and Sons.

Martin, Jozef. July 12, 1847. "Wanderungen im westlichen Siebenbürgen [Wanderings in Western Transylvania]." Oesterreichische Blätter für Literatur, Kunst, Geschichte, Geographie und Naturkunde [Austrian Journal for Literature, Art, History, Geography, and Natural Science] 4.157: 653.

Matis, Herbert and Karl Bachinger. 1973. "Österreichs industrielle Entwickelung [Austria's Industrial Development].” Die Habsburgermonarchie, 1848-1918 [The Habsburg Monarchy 1848-1918]. Alois Brusatti, ed. Vienna: Austrian Academy of Sciences, 1:210-232.

Matlekovits, Alexander. 1898. "The Ausgleich between Austria and Hungary." The Economic Journal 8.29: 17-27.

Matoš, Antun. 1900. “A Time to Remember.” Eugene Pantzer, Antun Gustav Matoš. 1981. Eugene Pantzer. Boston: Twayne Publishers: appendix.

Maxwell, Alexander a. 2005. "Multiple Nationalism: National Concepts in 19th century Hungary and Benedict Anderson's 'Imagined Communities'.” Nationalism and Ethnic Politics 11.3: 385-414.

Maxwell, Alexander b. 2007. "National Endogamy and Double Standards: Sexuality and Nationalism in East-Central Europe during the 19th Century." Journal of Social History 41.2: 413-33.

Maxwell, Alexander c. 2008. “'Der schöner, magyar, schnurbärtiger, bärtiger Mann': Nationaliserter Gesichtshaare in Ungarn im 19. Jahrhundert [The Beautiful, Hungarian, Mustachioed, Bearded Man: Nationalized Facial Hair in NineteenthCentury Hungary]." Haare zwischen Fiktion und Realität: Interdisziplinäre Untersuchungen zur Wahrnehmung der Haare [Hair Between Fiction and Reality: Interdisciplinary Investigations on Perceptions of Hair] Birgit Haas, ed. Münster: LIT: 180-204.

Maxwell, Alexander d. 2010. " 'It has Become a National Habit': Smoking and Masculinity in Hungary." Europe's Expansions and Contractions: Proceedings of the XVIIth Biennial Conference of the Australasian Association of European Historians. Evan Smith, ed. Adelaide: Australian Humanities Press: 177-98. Mazuchelli, Nina Elizabeth. 1882. Magyarland, Being the Narrative of our Travels through the Highlands and Lowlands of Hungary. Boston: Houghton Mifflin. Mednyánszky, Sándor [under the pseudonym Miss A.M. Birkbeck]. 1856. Rural and Historical Gleanings from Eastern Europe. London: Darton and Co. 
Maxwell, Alexander. "Tobacco as Cultural Signifier: A Cultural History of Masculinity and Nationality in Habsburg Hungary." AHEA: E-journal of the American Hungarian Educators Association, Volume 5 (2012): http://ahea.net/e-journal/volume-5-2012

Mikszáth, Kálmán a. 1962. "Prakovsky, the Deaf Blacksmith.” Sára Karig, trans. Hungarian Short Stories. István Sötér. Budapest: Corvina.

Mikszáth, Kálmán b. 1964. A Strange Marriage [Különös házasság]. István Farkas and Elisabeth West, trans. Budapest: Corvina.

Orosz, Jozeph. 1832. Ungarns gesetzgebender Körper auf dem Reichstage zu Pressburg im Jahre 1830 [Hungary's Lawgiving Bodies at the Pressburg Parliament of 1830]. Leipzig: Paul Gotthelf Kummer.

Paget, John. 1839. Hungary and Transylvania. London: John Murray.

Pateman, Carole a. 1988. The Sexual Contract. Palo Alto: Stanford University Press.

Pateman, Carole b. 1989. The Disorder of Women: Democracy, Feminism and Political Theory. Palo Alto: Stanford University Press.

Patterson, Arthur. 1869. The Magyars: Their Country and Institutions. London: Smith, Elder and co.

Plenker, Baron von. 1858. "The Manufacture, Trade, and Consumption of Tobacco." Merchant's Magazine and Commercial Review 39.

Quinn, Michael. 1836. A Steam Voyage Down the Danube. Paris: Galigani.

Reed, Richard. 2005. Birthing Fathers. Brunswick: Rutgers University Press.

Sandgruber, Roman a. 1982. Anfänge der Konsumgesellschaft [The Beginnings of Consumer Society]. Munich: Oldenbourg.

Sandgruber, Roman b. 1992. "Das Rauchen Genuß, Symbol, Gefahr von Neuguinea bis zu den Eskimos [The Pleasure, Symbolism and Danger of Smoking from New Guinea to the Eskimos]." Die Lasterhafte Panazee: 500 Jahre Tabakkultur in Europa [The Burdensome Panacea: 500 Years of Tobacco Culture in Europe]. Albert Rupp, ed. Vienna: Österreichische Tabakmuseum.

Schivelbusch, Wolfgang. 1981. Das Paradies, der Geschmack und die Vernunft: eine Geschichte der Genußmittel [Paradise, Taste, and Reason: A History of Luxury Foods]. Munich: Hanser.

Schlesinger, Max. 1850. The War in Hungary, 1848-1849. London: Richard Bentley. Silvestri, Gerhard, ed. 1860. Verhandlungen des verstärkten Reichsrathes [Proceedings of the Strengthened Reichsrat]. Vienna: Royal and Imperial Court Press. Vol. 1

Sked, Alan. 1979. The Survival of the Habsburg Empire. London, New York: Longman. Smith, Berkeley. 1903. Budapest: the City of the Magyars. London: Fischer Unwinn.

Szapary, Johann von. 1784. Der unthätige Reichtum Ungarns, wie zu gebrauchen [The Countless Riches of Hungary, How to Use Them]. Nürenberg: Johann Eberhard Zeh.

Széchenyi, István. 1830. Hitel. Pest: Trattner.

Székács, Pál. 1844. “A kis dohányzóhoz [About a Little Smoking].” Pesti Divatlap [Pest Fashion Journal] 1.11: 331.

Szekfü, Gyula. 1926. Iratok a magyar államnyelv kérdésének történetéhey 1790-1848 [Writings about the Hungarian Official State Language Question, 1790-1848]. Budapest: Magyar Történelmi Társulat.

Tihany, Leslie. 1969. "The Austro-Hungarian Compromise, 1867-1918: A Half-Century of Diagnosis; Fifty Years of Post-Mortem." Central European History 2.2: 11438. 
Maxwell, Alexander. "Tobacco as Cultural Signifier: A Cultural History of Masculinity and Nationality in Habsburg Hungary." AHEA: E-journal of the American Hungarian Educators Association, Volume 5 (2012): http://ahea.net/e-journal/volume-5-2012

Tóth, Árpád. 2007. "Voluntary Society in Mid-19 ${ }^{\text {th }}$ Century Pest: Urbanization and the Changing Distribution of Power." Who Ran the Cities? Elite and Urban Power Structures, 1700-2000. Ralf Rot and Robert Beachy, eds. London: Ashgate: 16970.

Vantuch, Anton and Ludovít Holotík, eds. 1971. Der österreichisch-ungarische Ausgleich 1867 [The Austro-Hungarian Compromise, 1867] Bratislava: Slovak Academy of Sciences.

Varga, János. 1993. A Hungarian Quo Vadis: Political Trends and Theories of the Early 1840s. Budapest: Akadémiai.

Vermes, Gábor. 1995. "Szechenyi and Posterity: Changing Perceptions about Szechenyi in the 19th and 20th Centuries." East European Quarterly 29.2: 157-67.

Viszota, Gyula, ed. 1926. Gróf Széchenyi István naplói [Count István Széchenyi’s Diary] Budapest: Magyar Tudomanos Akadémia.

Vojdisek, Joseph. 1830. Ueber den Credit [Hitel] (Credit) Leipzig: Wigand.

Weber, Nora. 1997. "Feminism, Patriarchy, Nationalism, and Women in Fin-de-Siècle Slovakia.” Nationalities Papers 25.1: 35-65.

Wenkstern, Otto. 1859. A History of the War in Hungary in 1848 and 1849. London: John Parker.

Wynne, R.E.. 1968. "The Austro-Hungarian Ausgleich of 1867, some Historians' Views." Historical Papers / Communications historiques 3.1: 189-214.

Zelovich, Kornél. 1999. "István Széchenyi: The Greatest Consultant Engineer of Hungary." Britain and Hungary: Contacts in Architecture and Design. Gyula Ernyey. Budapest: Hungarian University of Craft and Design: 13-30.

Žižek, Slavoj. 2004. Organs Without Bodies: On Deleuze and Consequences. New York: Routledge. 